\title{
Enhancement of Iron-Based Photo-Driven Processes by the Presence of Catechol Moieties
}

\author{
Javier Moreno-Andrés *,+므, Iván Vallés, Paula García-Negueroles, Lucas Santos-Juanes and Antonio Arques * \\ Grupo de Procesos de Oxidación Avanzada, Departamento de Ingeniería Textil y Papelera, Campus de Alcoy, \\ Universitat Politècnica de València, 03801 Alcoy, Spain; ivvalfer@epsa.upv.es (I.V.); \\ paugarne@txp.upv.es (P.G.-N.); lusanju1@txp.upv.es (L.S.-J.) \\ * Correspondence: javier.moreno@uca.es (J.M.-A.); aarques@txp.upv.es (A.A.) \\ + Present address: Department of Environmental Technologies, Faculty of Marine and Environmental Sciences, \\ INMAR-Marine Research Institute, CEIMAR_-International Campus of Excellence of the Sea, University of \\ Cadiz, Campus Universitario de Puerto Real, 11510 Cádiz, Spain.
}

check for

updates

Citation: Moreno-Andrés, J.; Vallés,

I.; García-Negueroles, P.;

Santos-Juanes, L.; Arques, A.

Enhancement of Iron-Based

Photo-Driven Processes by the Presence of Catechol Moieties.

Catalysts 2021, 11, 372. https://

doi.org/10.3390/catal11030372

Academic Editor: Detlef W.

Bahnemann

Received: 12 February 2021

Accepted: 8 March 2021

Published: 12 March 2021

Publisher's Note: MDPI stays neutral with regard to jurisdictional claims in published maps and institutional affiliations.

Copyright: (c) 2021 by the authors. Licensee MDPI, Basel, Switzerland. This article is an open access article distributed under the terms and conditions of the Creative Commons Attribution (CC BY) license (https:/ / creativecommons.org/licenses/by/ $4.0 /)$.

\begin{abstract}
Photo-induced Advanced Oxidation Processes (AOPs) using $\mathrm{H}_{2} \mathrm{O}_{2}$ or $\mathrm{S}_{2} \mathrm{O}_{8}{ }^{2-}$ as radical precursors were assessed for the abatement of six different contaminants of emerging concern (CECs). In order to increase the efficiency of these AOPs at a wider $\mathrm{pH}$ range, the catechol organic functional compound was studied as a potential assistant in photo-driven iron-based processes. Different salinity regimes were also studied (in terms of $\mathrm{Cl}^{-}$concentration), namely low salt water $\left(1 \mathrm{~g} \cdot \mathrm{L}^{-1}\right)$ or a salt-water $\left(30 \mathrm{~g} \cdot \mathrm{L}^{-1}\right)$ matrix. Results obtained revealed that the presence of catechol could efficiently assist the photo-Fenton system and partly promote the photo-induced $\mathrm{S}_{2} \mathrm{O}_{8}{ }^{2-}$ system, which was highly dependent on salinity. Regarding the behavior of individual CECs, the photo-Fenton reaction was able to enhance the degradation of all six CECs, meanwhile the $\mathrm{S}_{2} \mathrm{O}_{8}{ }^{2-}$-based process showed a moderate enhancement for acetaminophen, amoxicillin or clofibric acid. Finally, a response-surface methodology was employed to determine the effect of $\mathrm{pH}$ and catechol concentration on the different photo-driven processes. Catechol was removed during the degradation process. According to the results obtained, the presence of catechol in organic macromolecules can bring some advantages in water treatment for either freshwater (wastewater) or seawater (maritime or aquaculture industry).
\end{abstract}

Keywords: phenolic moieties; photo-Fenton; persulfate; emerging contaminants; Fe-binding ligands; iron chelates

\section{Introduction}

Fenton-based processes are among the most promising Advanced Oxidation Processes (AOPs) for water detoxification and, specifically, for the abatement of Contaminants of Emerging Concern (CECs), for which conventional treatment methods are poorly effective [1]. These processes are based on the Haber-Weiss reaction, where iron salts catalyze the decomposition of $\mathrm{H}_{2} \mathrm{O}_{2}$ into highly oxidizing hydroxyl radicals and/or other reactive oxygen species [2-5], briefly described by Equations (1) and (2) (Equation (1): $\mathrm{k}=63 \mathrm{M}^{-1} \cdot \mathrm{s}^{-1}$; Equation (2): $\mathrm{k}=0.01-0.001 \mathrm{M}^{-1} \cdot \mathrm{s}^{-1}$ ). It may occur naturally in aquatic ecosystems [6-8] but they can also be applied in engineered water systems [1,9]. Iron ions can also activate persulfate salts (Equation (3); $\mathrm{k}=12-27 \mathrm{M}^{-1} \cdot \mathrm{s}^{-1}$ ) to produce sulfate radicals, which are also powerful oxidants but with higher selectivity and longer life-time (half-life: $30-40 \mu \mathrm{s}$ ) in comparison with ${ }^{\bullet} \mathrm{OH}$ (half-life: $10^{-3} \mu \mathrm{s}$ ) [10].

Iron speciation plays a significant role in Fenton chemistry, but iron deactivation also occurs at $\mathrm{pH}$ above 3 , which limits the applicability of these iron-based processes in mildly acidic or basic medium [4]. Accordingly, research on strategies to enhance the regeneration of ferrous iron in both Fenton and persulfate-based systems are now receiving increasing attention. For instance, the use of organic ligands able to form photoactive compounds with $\mathrm{Fe}(\mathrm{III})$ has been examined, using different substances for this purpose 
such as oxalate, citrate, EDTA or EDDS [9,11,12]. Since they have to be added to the solution, their biodegradability and/or potential toxicity are key factors for their use in water treatment systems. Hence, searching for naturally occurring substances to be used as chemical auxiliaries for photo-Fenton processes has received scientific interest.

$$
\begin{gathered}
\mathrm{Fe}^{2+}+\mathrm{H}_{2} \mathrm{O}_{2} \rightarrow \mathrm{Fe}^{3+}+\mathrm{OH}^{-}+\bullet \mathrm{OH} \\
\mathrm{Fe}^{3+}+\mathrm{H}_{2} \mathrm{O}_{2} \rightarrow \mathrm{Fe}^{2+}+\mathrm{HO}_{2}{ }^{\bullet}+\mathrm{H}^{+} \\
\mathrm{Fe}^{2+}+\mathrm{S}_{2} \mathrm{O}_{8}{ }^{2-} \rightarrow \mathrm{Fe}^{3+}+2 \mathrm{SO}_{4}^{\bullet-}
\end{gathered}
$$

The use of iron for living organisms is essential for growth but its low solubility at physiological $\mathrm{pH}$ also limits its availability [13]. In this sense, most of the Fe available in aquatic ecosystems is found complexed by organic Fe-binding ligands $[8,14]$. These organic chelates, which are known as the Fe ligand pool, can be released by microorganisms, or generated as transformation products of natural organic matter. For instance, an interesting source of iron ligands is siderophore production by microorganisms [14]. They are defined as iron chelates produced mainly by bacterial cells, which facilitate uptake of iron into the microorganisms. Siderophores are typically classified in the basis of their chemical nature and functional groups; among them can be found catecholates (also so-called phenolates), which are present in several bacterial and cyanobacterial species $[13,15,16]$. These functional groups are considered a major contributor to the stability of metal-siderophore complexes.

Another interesting source of iron ligands are humic-like substances, which have been shown to be efficient for the enhancement of photo-Fenton processes (Table 1) [17-19]. Interestingly, a recent study suggests that iron chelated by humic substances is the major reservoir of Fe-complexed in oceans [20]. Humic substances are complex organic macromolecules with some specific functional groups, such as carboxylic, carbonyl or catechol moieties [21,22]. These functional groups have been employed as simplified model compounds to simulate the effect of humic-like substances in different processes such as sorption [22] or photo-oxidation of As(III) [21].

The catechol organic functional compound presents moderate binding capacity with Fe (III) $\left(\log K_{1}=20.01\right)[15,23]$ and high photo-reactivity as a free ligand [24]. This UV photo-reactivity of the Fe (III) complex is important since leads to oxidation of the ligand and reduction of Fe (III) to Fe (II) generally through Equation (4), thus could introduce Fe (II) again into the Fenton cycle. It has been proposed that once catechol is bound to Fe (III), the metal is reduced to Fe (II) [25-27], while the ligand is oxidized to a quinone (via semiquinone). Quinone-intermediates can regenerate themselves (mainly by reaction with $\mathrm{HO}_{2} \bullet$ species, which are abundant in Fenton-based processes) and might result in a catalytic redox cycle $[25,26,28]$. However, most of studies have been focused on catechol as target pollutant, as it is an intermediate of phenol degradation [10,29-31], but very few have investigated on the enhancement of Fenton-based process by the catechol Fecomplexes $[25,26,28,32]$.

$$
\mathrm{Fe}^{\mathrm{III}}-\mathrm{L}+\mathrm{h} v \rightarrow \mathrm{Fe}^{2+}+\mathrm{L}^{\bullet+}
$$

In this scenario, the main goal of this study is to investigate catechol as a possible assistant in photo-driven iron-based processes for water treatment, namely the photoFenton process, i.e., $\mathrm{H}_{2} \mathrm{O}_{2}$-based, or persulfate (PDS; $\mathrm{S}_{2} \mathrm{O}_{8}{ }^{2-}$-based) process. This is interesting in two ways: (i) the possibility of using catechol as auxiliary for iron-based AOPs and (ii) to be employed as a surrogate to better understand the behavior of complex macromolecules such as humic-like substances (HLS) where catechol moieties can act as active sites for iron complexation and to drive photo-Fenton-like reactions.

Six different contaminants of emerging concern (CECs) were used as target contaminants, namely acetamiprid (insecticide), amoxicillin (antibiotic), acetaminophen (analgesic), caffeine (stimulating agent), clofibric acid (metabolite of clofibrate, also employed as herbicide) and carbamazepine (psychiatric drug). They were selected according to: (i) their presence in different effluents from diverse origin, such as aquaculture, urban wastewater, 
shipping, membrane rejection [33-38], (ii) their detection in natural waters [38-40] but also (iii) their inclusion on the European monitoring list, i.e., the Watch List of Substances (Decision 2018/840/EU), in which amoxicillin and acetamiprid are included.

Table 1. Previous studies that make use of Humic-like Substances for the enhancement of Photo-Fenton processes. OMWHLS: Olive Mill Waste humic like substances. SBO: Soluble Bio-Organic substances.

\begin{tabular}{|c|c|c|c|c|c|}
\hline $\begin{array}{l}\text { Humic Like } \\
\text { Substances }\end{array}$ & $\begin{array}{l}\text { Concentration } \\
\text { of HLS Tested }\end{array}$ & $\begin{array}{c}\text { Operational } \\
\text { Variables } \mathrm{pH} / \mathrm{H}_{2} \mathrm{O}_{2}\end{array}$ & Target Compounds & Improvement & References \\
\hline OMW-HLS & $\begin{array}{l}10 \mathrm{mg} \mathrm{L}^{-1} \\
30 \mathrm{mg} \mathrm{L}^{-1} \\
60 \mathrm{mg} \mathrm{L}^{-1}\end{array}$ & $\begin{array}{c}\text { pH } 5 \\
{\left[\mathrm{H}_{2} \mathrm{O}_{2}\right]=60 \mathrm{mg} \mathrm{L}^{-1}}\end{array}$ & Caffeine & $\begin{array}{l}\text { Removal of } 95 \% \text { of } \\
\text { initial amount at } \\
10 \text { min with } \\
10 \mathrm{mg} \mathrm{L}^{-1} \text { of HLS vs. } \\
45 \% \text { removal without } \\
\text { these substances. }\end{array}$ & $\begin{array}{c}\text { García-Ballesteros et al., } \\
2018 \text { [18] }\end{array}$ \\
\hline \multirow[b]{2}{*}{$\begin{array}{c}\text { SBO from } \\
\text { urban wastes }\end{array}$} & $30 \mathrm{mg} \mathrm{L}^{-1}$ & $\begin{array}{c}\text { pH } 5 \\
{\left[\mathrm{H}_{2} \mathrm{O}_{2}\right]=60 \mathrm{mg} \mathrm{L}^{-1}}\end{array}$ & Caffeine & $\begin{array}{l}\text { Removal of } 100 \% \text { of } \\
\text { initial amount at } \\
90 \text { min. vs. } 60 \% \\
\text { removal without } \\
\text { these substances. }\end{array}$ & $\begin{array}{l}\text { García-Negueroles et al., } \\
2019 \text { [17] }\end{array}$ \\
\hline & $10 \mathrm{mg} \mathrm{L}^{-1}$ & $\begin{array}{c}\text { pH } 5.2 \\
{\left[\mathrm{H}_{2} \mathrm{O}_{2}\right]=75 \mathrm{mg} \mathrm{L}^{-1}}\end{array}$ & $\begin{array}{l}\text { Acetaminophen, } \\
\text { amoxicillin, caffeine, } \\
\text { acetamiprid, } \\
\text { carbamazepine and } \\
\text { clofibric acid. }\end{array}$ & $\begin{array}{l}\text { Removal of } 100 \% \text { of } \\
\text { initial amount of } \\
4 \text { pollutants at } \\
t_{30 \mathrm{w}}=30 \text { min vs. } \\
80 \text { min }\left(t_{30 \mathrm{w}}\right) \text { needed } \\
\text { in absence of } \\
\text { these substances. }\end{array}$ & Gomis et al., 2014 [41] \\
\hline
\end{tabular}

In order to address the water matrix, different salinity regimes were studied, namely low salt water (LSW) or a salt-water (SW) matrix, so as to represent fresh and saline water effluents. To gain further insight into the action mode of both $\mathrm{H}_{2} \mathrm{O}_{2}$ and PDS systems, scavenging tests were performed with the tested CECs splitting into two groups, in accordance with their different reactivity with sulfate or hydroxyl radicals. Finally, a response surface methodology based on Doehlert design was employed to determine the effect of $\mathrm{pH}$ and catechol concentration on the different photo-driven processes. Accordingly, the main hypothesis is that catechol can accelerate photo-driven iron-based processes in a wide $\mathrm{pH}$ and salinity range. Their potential use can entail biomimetics and some advantages in water treatment for either fresh water (wastewater) or saline water (maritime or aquaculture industry).

\section{Results and Discussion}

\subsection{Effect of Catechol in Photo-Fenton and Persulfate-Based Systems}

A first series of experiments was devoted to assessing the role of catechol in both photo-induced processes, i.e., a $\mathrm{H}_{2} \mathrm{O}_{2}$-based (Fenton) and a persulfate-based system at $\mathrm{pH}=5$. Time resolved data of the cumulative concentration of the $\Sigma$ CECs were obtained (Figure 1A). Figure 1A compares photo-Fenton processes without and with catechol, in both low and high salinity matrices but also including a control experiment in the absence of chlorides, i.e., distilled water (DW). A very strong enhancement of the process can be observed as the concentration of CECs was negligible after $15 \mathrm{~min}$ of irradiation when catechol (CAT) was present, while significant amounts remained even after $60 \mathrm{~min}$ (ca. $20 \%$ in SW and $10 \%$ in LSW) in the absence of CAT. This fact might be attributed to the formation of a complex between iron and CAT that prevents inactivation of the catalytic role of iron at mild $\mathrm{pH}$. 


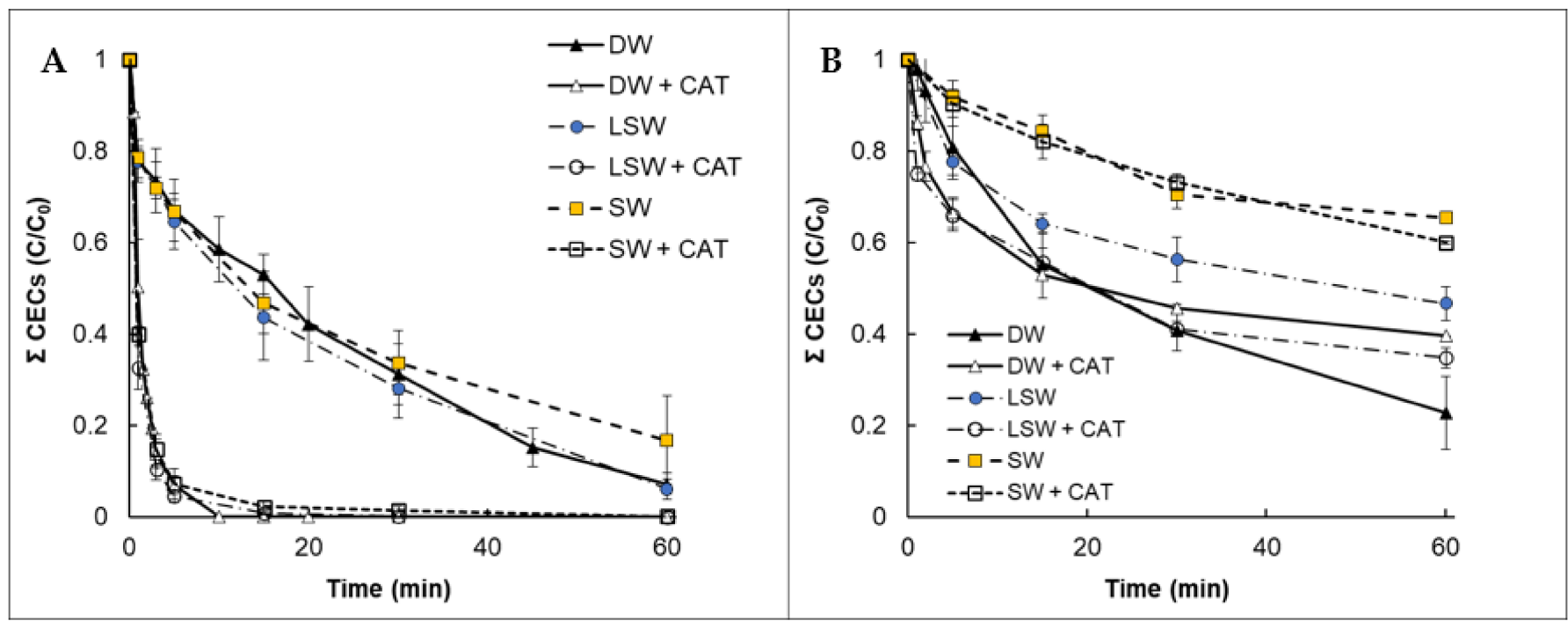

Figure 1. Degradation profiles of sum of the total concentration of contaminants of emerging concern (CECs) in Distilled Water (DW), low salt water (LSW), and salt-water (SW) matrix matrices under (A) a photo-Fenton system $\left(\mathrm{Fe}(\mathrm{III}) / \mathrm{H}_{2} \mathrm{O}_{2}\right)$ in the presence and absence of catechol (CAT). (B) Fe(III)/persulfate (PDS) system in the presence and absence of catechol (CAT). Experimental conditions: $\left([\mathrm{Fe}(\mathrm{III})]=5 \mathrm{mg} \cdot \mathrm{L}^{-1},\left[\mathrm{H}_{2} \mathrm{O}_{2}\right]\right.$ or $\left.\left[\mathrm{S}_{2} \mathrm{O}_{8}{ }^{2-}\right]=146 \mathrm{mg} \cdot \mathrm{L}^{-1},[\mathrm{CAT}]=13 \mathrm{mg} \cdot \mathrm{L}^{-1} ; \mathrm{pH} \mathrm{H}_{0}=5\right)$.

By comparison with previous studies, similar trends have been observed when Humiclike Substances (HLS) are used as auxiliaries of the photo-Fenton reaction (Table 1). For instance, García-Ballesteros et al. 2018 [18] and García-Negueroles et al. 2019 [17] concluded that the degradation of caffeine (in a photo-Fenton system at $\mathrm{pH}=5$ ) was increased by the addition of different HLS in the range of 10-60 mg. $\mathrm{L}^{-1}$. Moreover, Gomis et al. 2014 [41], tested soluble bio-based substances (with the presence of phenolic carbon, phenoxy and carboxylic functional groups), obtaining an enhancement of the photo-Fenton reaction at $\mathrm{pH}$ 5.2. Thus, if catechol (and in general phenolic moieties) can be assumed to be among the active sites of these HLS it might be proposed as a simplified model compound to simulate the effect of HLS on oxidation processes [21,22].

Following the same approach as with the photo-Fenton reaction, the ability of iron to activate PDS was assessed under irradiation (Figure 1B). As has been mentioned in the Introduction, PDS can be activated by $\mathrm{Fe}^{2+}$ (Equation (3)) but also by irradiation $\left(\mathrm{S}_{2} \mathrm{O}_{8}{ }^{2-}+\mathrm{hv} \rightarrow \mathrm{SO}_{4}{ }^{--}\right)$, so these two activation factors are expected sources of radical production [42]. Additionally, irradiation can also photo-reduce the ferric iron-complexes into ferrous iron (Equation (4)). Thus, the presence of CAT in PDS system is expected to assist the formation of $\mathrm{Fe}^{2+}$ through photoreduction of $\mathrm{Fe}(\mathrm{III})-\mathrm{CAT}$ complexes. The degradation profiles of the $\Sigma$ CECs according to the irradiation time are depicted in Figure 1B, where a series of experiments were performed with the presence of CAT at $\mathrm{pH}=5$ and compared with the results obtained in the absence of catechol. In both DW and LSW, a slight improvement can be perceived when catechol is present in the solution. For instance, in LSW, the $\Sigma$ CECs reaches degradation of $53.4 \%$ and $65.3 \%$ with and without catechol in solution, respectively. In contrast, the PDS-based process was scarcely efficient in SW, either with or without CAT in solution.

High salinity (in terms of $\mathrm{Cl}^{-}$concentration) generally seems to decrease the efficiency of both processes, which is especially remarkable in the PDS-based system. In the presence of chlorides, $\mathrm{Fe}$ (III) can yield to $\mathrm{Fe}(\mathrm{Cl})^{2+}$ and $\mathrm{FeCl}_{2}{ }^{+}$complexes, which are highly photo-active and can promote the iron reduction into $\mathrm{Fe}$ (II) and chloride radicals (Equations (5) and (6)) [43,44]. This fact might explain the slight improvement of the photoFenton process in LSW. On the other hand, chlorides also present an scavenging effect with - OH radicals (Equations (7)-(10)) [44,45]. The generation of these chloride radicals (less reactive and with higher selectivity) might be the reason for which a slowing down of the photo-Fenton process is observed as salinity increases, as observed in SW. However, the 
presence of catechol in solution, could successfully assist the photo-Fenton process, since similar results were obtained in DW, LSW and SW matrices (Figure 1A).

$$
\begin{gathered}
\mathrm{Fe}(\mathrm{Cl})^{2+}+\mathrm{hv} \rightarrow \mathrm{Fe}^{2+}+\mathrm{Cl}^{\bullet} \\
\mathrm{FeCl}_{2}^{+}+\mathrm{h} v \rightarrow \mathrm{FeCl}^{+}+\mathrm{Cl}^{\bullet} \\
\bullet \mathrm{OH}+\mathrm{Cl}^{-} \leftrightarrows \mathrm{ClOH}^{\bullet-} \leftrightarrows \mathrm{OH}^{\bullet} \mathrm{Cl}^{-} \\
\mathrm{ClOH}^{\bullet-}+\mathrm{H}^{+} \rightarrow \mathrm{Cl}^{\bullet}+\mathrm{H}_{2} \mathrm{O} \\
\bullet \mathrm{OH}+\mathrm{Cl}^{-}+\mathrm{O}_{2} \rightarrow \mathrm{ClOH}+\mathrm{O}_{2}^{\bullet-} \\
\mathrm{ClOH}^{\bullet-}+\mathrm{Cl}^{-} \rightarrow \mathrm{Cl}_{2}^{\bullet-}+\mathrm{OH}^{-}
\end{gathered}
$$

Similarly, sulfate radicals can also interact with chlorides in solution, giving as a result less reactive radicals such as $\mathrm{Cl}^{\bullet}, \mathrm{Cl}_{2}{ }^{\bullet-}$ (Equations (11) and (12)). In fact, it is worth noticing that $\mathrm{Cl}^{-}$oxidation is more favored by $\mathrm{SO}_{4}{ }^{--}$than ${ }^{\bullet} \mathrm{OH}[46,47]$. This might explain the poor performance of the system in high salinity matrix for the PDS system (Figure 1B). Additionally, it is known that both sulfate and chloride radicals can selectively react with specific compounds $[46,48-50]$. In this regard, some insights by assessing individual CECs will be addressing in the next sub-section.

$$
\begin{gathered}
\mathrm{SO}_{4}^{\bullet-}+\mathrm{Cl}^{-} \leftrightarrows \mathrm{Cl}^{\bullet}+\mathrm{SO}_{4}^{2-} \\
\mathrm{Cl}^{\bullet}+\mathrm{Cl}^{-} \rightarrow \mathrm{Cl}_{2}^{\bullet-}+\mathrm{H}_{2} \mathrm{O}
\end{gathered}
$$

\subsection{Some Insights by Assessing Individual Behavior of the Different CECS}

To gain further insight into the action mode of both $\mathrm{H}_{2} \mathrm{O}_{2}$ and $\mathrm{S}_{2} \mathrm{O}_{8}{ }^{2-}$ radical precursors, the tested CECs were classified into two groups in accordance to their different reactivity with sulfate or hydroxyl radicals [48,50-52]. Thus, group I includes those compounds that exhibit higher reactivity with $\bullet \mathrm{OH}$, rather than $\mathrm{SO}_{4}{ }^{\bullet-}$ (i.e., carbamazepine, caffeine and acetamiprid), with $\mathrm{k}_{\bullet} \mathrm{OH} \approx 6 \times 10^{9} \mathrm{M}^{-1} \cdot \mathrm{s}^{-1} ; \mathrm{k}_{\mathrm{SO} 4 \bullet-} \approx 1-3 \times 10^{9} \mathrm{M}^{-1} \cdot \mathrm{s}^{-1}$. Group II includes the compounds that could have more affinity for reaction with $\mathrm{SO} 4^{\bullet-}$ (i.e., clofibric acid, amoxicillin and acetaminophen), with $\mathrm{k}_{\mathrm{SO} 4 \bullet-} \approx 2-7 \times 10^{9} \mathrm{M}^{-1} \cdot \mathrm{s}^{-1}$.

Degradation curves can be divided into both groups: Figure 2-upper (group I) and Figure 2-lower (group II). Although similar results and trends are observed among groups I and II in the photo-Fenton process, some differences can be found in the PDS system. Here, lower degradation rates can be observed for those compounds belonging to group I, with similar trends in DW, LSW and SW matrices (Figure 2-upper). Interestingly, these results match with recent studies that make use of similar target pollutants [53]. On the contrary, degradation rates of group II compounds notably increase in the three aqueous solutions (Figure 2-down).

In general, ${ }^{\bullet} \mathrm{OH}$ has a high oxidation potential (ca. $2.8 \mathrm{~V}$ ), and that of sulfate radical is $2.43 \mathrm{~V}$ [54]. This makes $\mathrm{SO}_{4}{ }^{\bullet-}$ show higher selectivity towards some substances, giving in general fast reactions towards aromatic rings that are activated for electrophilic attack. It is the case of acetaminophen, clofibric acid and amoxicillin, with electro-donating groups directly attached to the ring. On the other hand, the pyridinic group of acetamiprid or the imidazole moiety of caffeine are reluctant to attack electrophilically, this explaining the bad performance of the sulfate radical towards these compounds.

Accordingly, in the case of group II compounds, the addition of CAT can promote the efficiency of the PDS-based system in both LSW and SW, which means that the time to reach $50 \%$ of degradation is reduced by approximately half in the presence of CAT in solution. On the other hand, the selectivity of primary sulfate radicals can limit the process to specific contaminants, since no effect has been observed in compounds of group I. In consequence, the limited efficiency of PDS system has been obtained (Section 2.1) when the sum of whole contaminants is studied. 


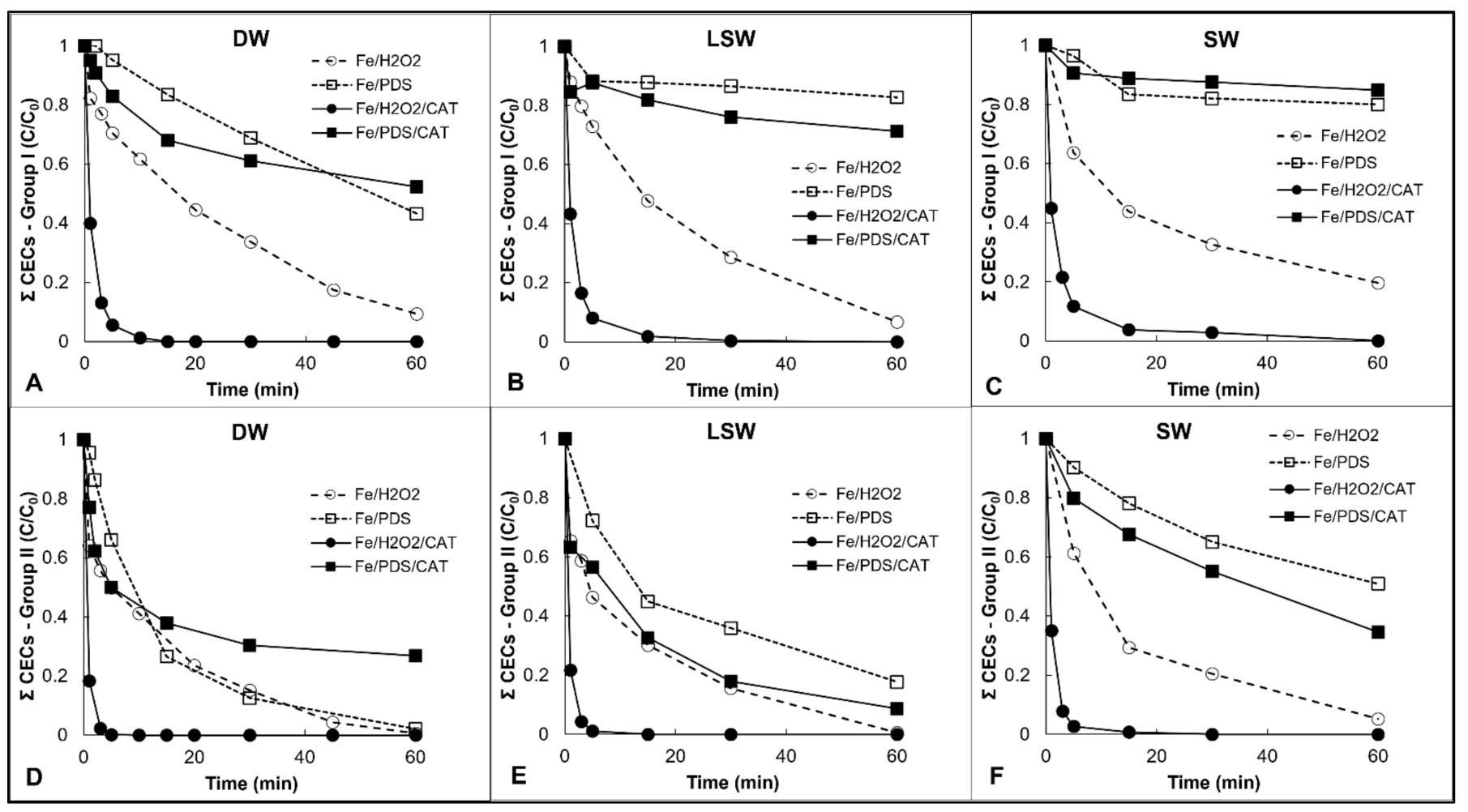

Figure 2. Degradation profiles of the sum of CECs in a photo-Fenton system $\left(\mathrm{Fe} / \mathrm{H}_{2} \mathrm{O}_{2}\right)$ and irradiated Fe/PDS system with the presence/absence of catechol (CAT) in DW (A,D) LSW (B,E) and SW (C,F). CECs have been split into Group I (Upper): Carbamazepine, Caffeine and Acetamiprid; and Group II (Down): Clofibric acid, Amoxicillin and Acetaminophen. Standard Deviation of each experimental point is always S.D. $<0.05$. Experimental conditions: $[\mathrm{Fe}(\mathrm{III})]=5 \mathrm{mg} \cdot \mathrm{L}^{-1},\left[\mathrm{H}_{2} \mathrm{O}_{2}\right]$ or $[\mathrm{PDS}]=146.16 \mathrm{mg} \cdot \mathrm{L}^{-1},[\mathrm{CAT}]=13 \mathrm{mg} \cdot \mathrm{L}^{-1}, \mathrm{pH}=5$.

Scavenging experiments were also performed to consider the involvement of different radical species. 2-Propanol $\left(\mathrm{k}_{\bullet} \mathrm{OH}^{-2}-\right.$ Prop $=1.9 \times 10^{9} \mathrm{M}^{-1} \cdot \mathrm{s}^{-1} ; \mathrm{k}_{\mathrm{SO} 4 \bullet-}-2-$ Prop $\left.=6.9 \times 10^{7} \mathrm{M}^{-1} \cdot \mathrm{s}^{-1}\right)$, and tert-butanol $(\mathrm{t}-\mathrm{BuOH})\left(\mathrm{k}_{\bullet} \mathrm{OH}^{-} \mathrm{t}-\mathrm{BuOH}=6 \times 10^{8} \mathrm{M}^{-1} \cdot \mathrm{s}^{-1} ; \mathrm{k}_{\mathrm{SO} 4 \bullet-}{ }^{-\mathrm{t}-\mathrm{BuOH}}=8.4 \times 10^{5} \mathrm{M}^{-1} \cdot \mathrm{s}^{-1}\right)$ were used as radical probes, considering that 2-propanol can effectively quench both $\bullet \mathrm{OH}$ and $\mathrm{SO}_{4} \bullet-$, while $\mathrm{t}-\mathrm{BuOH}$ selectively reacts with $\bullet \mathrm{OH}[55,56]$. The same approach has been performed successfully in previous studies [42]. Accordingly, the results obtained are depicted in Figure 3, where the presence of scavengers was assessed in SW matrix at operational conditions of $[\mathrm{Fe}(\mathrm{III})]=5 \mathrm{mg} \cdot \mathrm{L}^{-1},[\mathrm{CAT}]=13 \mathrm{mg} \cdot \mathrm{L}^{-1}, \mathrm{pH}_{0}=5$.

For compounds of group I, a similar degradation rate was obtained for the PDS system in the presence of both scavengers (Figure 3A). However, in the photo-Fenton system, a clear inhibition in the presence of 2-propanol is observed (Figure 3B), which suggests a major role in degradation for hydroxyl radicals. On the other hand, for compounds of group II, slight inhibition is observed in the PDS system, majorly attributed to $\mathrm{SO}_{4}^{\bullet-}$, but also to $\bullet \mathrm{OH}$ derived from the photolysis of iron-aqua complexes (Figure 3C). In the photo-Fenton system, the degradation of CECs is notably inhibited (28\%), although at a minor rate than group I compounds (56\%).

Those results support that $\bullet \mathrm{OH}$ radicals play a major role in CECs degradation of both group I and group II compounds. Furthermore, they also suggest that the role of $\mathrm{SO}_{4}{ }^{\bullet-}$ in CECs degradation is slightly higher for group II, and almost negligible in compounds of group I, supporting the selectivity of these $\mathrm{SO}_{4}{ }^{\bullet-}$ towards specific compounds. It is also noteworthy that, despite the presence of scavengers, the CECs degradation is remarkable, especially for those pollutants of group II. Thus, the involvement of other reactive species is expected. Taking into account the high $\mathrm{Cl}^{-}$concentration, probably $\mathrm{Cl}^{\bullet}$ and $\mathrm{Cl}_{2}{ }^{\bullet-}$ radicals are also taking part in the degradation process, due to the rapidly oxidation of $\mathrm{Cl}^{-}$in the presence of $\mathrm{SO}_{4}{ }^{\bullet-}\left(\mathrm{kSO}_{\mathrm{SO}} \bullet{ }_{-}^{-} \mathrm{Cl}-{ }^{-}=3-6.6 \times 10^{8} \mathrm{M}^{-1} \cdot \mathrm{s}^{-1}\right)$ and $\bullet \mathrm{OH}$ 
$\left(\mathrm{k}_{\bullet} \mathrm{OH}^{-} \mathrm{Cl}-=3-4.3 \times 10^{9} \mathrm{M}^{-1} \cdot \mathrm{s}^{-1}\right)$, especially suitable for the production of $\mathrm{Cl}_{2}{ }^{\bullet-}[56,57]$. Additionally, the high reactivity of $\mathrm{Cl}_{2}{ }^{\bullet-}$ radicals with compounds of group II, such as acetaminophen $\left(\mathrm{k}_{\mathrm{Cl} 2 \bullet-}=4.32 \times 10^{8} \mathrm{M}^{-1} \cdot \mathrm{s}^{-1}\right)$ in front of compounds of group I, such as carbamazepine $\left(\mathrm{k}_{\mathrm{Cl} 2 \bullet-}=0.43 \times 10^{8} \mathrm{M}^{-1} \cdot \mathrm{s}^{-1}\right)$ supports the results obtained [49].

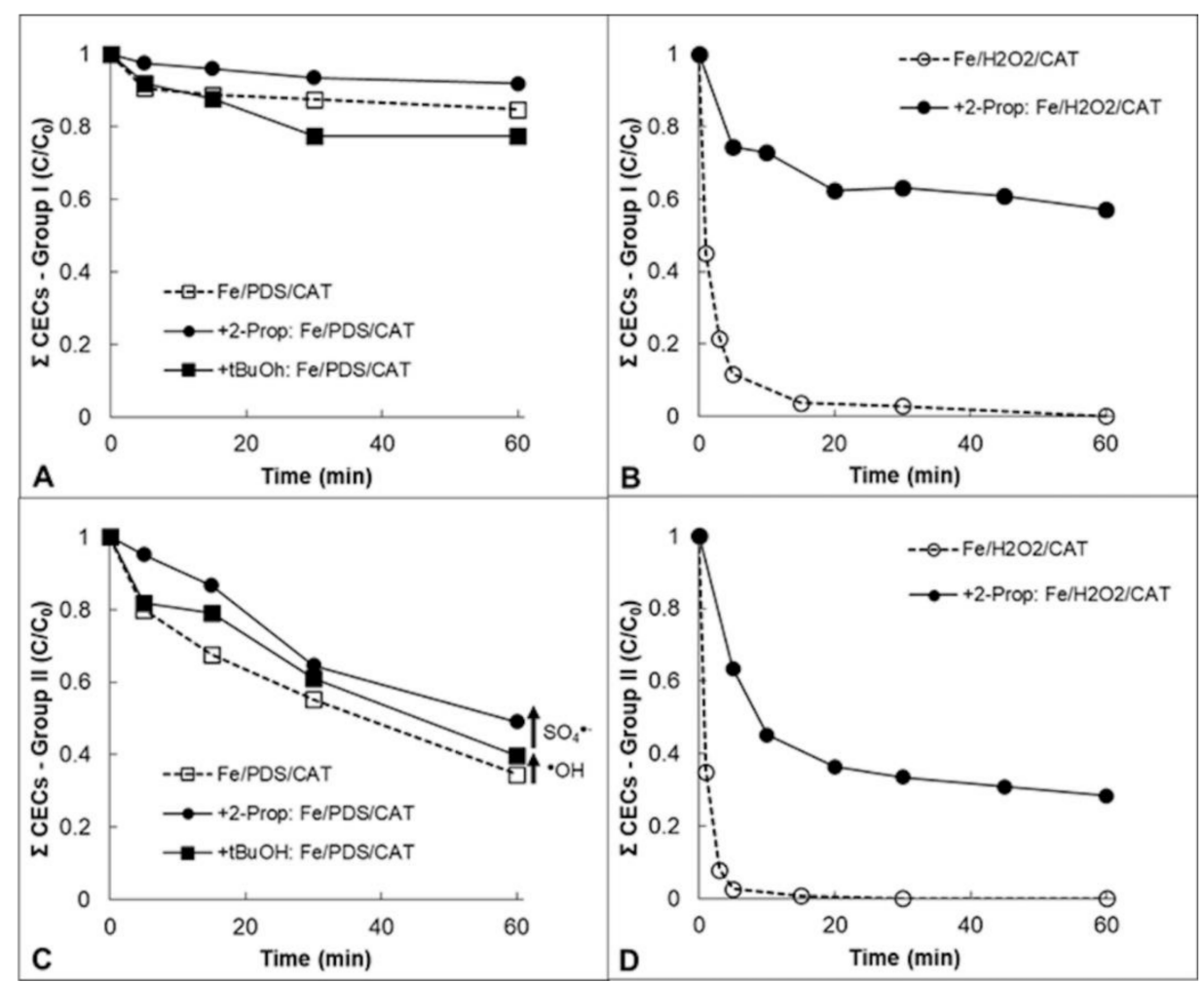

Figure 3. Degradation profiles of the sum of CECs in an irradiated Fe/PDS/CAT system $(\mathbf{A}, \mathbf{C})$ and photo-Fenton system $\left(\mathrm{Fe} / \mathrm{H}_{2} \mathrm{O}_{2} / \mathrm{CAT}\right)(\mathbf{B}, \mathbf{D})$ with the presence of scavengers in SW. CECs have been split into Group I (A,B): Carbamazepine, Caffeine and Acetamiprid; and Group II (C,D): Clofibric acid, Amoxicillin and Acetaminophen. Experimental conditions: $[\mathrm{Fe}(\mathrm{III})]=5 \mathrm{mg} \cdot \mathrm{L}^{-1},\left[\mathrm{H}_{2} \mathrm{O}_{2}\right] /[\mathrm{PDS}]$ $=146.16 \mathrm{mg} \cdot \mathrm{L}^{-1},[\mathrm{CAT}]=13 \mathrm{mg} \cdot \mathrm{L}^{-1}, \mathrm{pH}_{0}=5$.

\subsection{Effect of Operational Factors and Reagents Consumption}

In order to study how $\mathrm{pH}$ and [CAT] influences in the different photo-induced systems (Fenton-based and PDS-based), a two-variable Doehlert matrix design was employed (see Table 2 for experimental points). The time required for the removal of $50 \%$ of the CECs $\left(t_{50} \%\right)$ was estimated from the plot of $\Sigma$ CECs vs. irradiation time. A detailed discussion on this parameter can be found elsewhere [19].

\subsubsection{Photo-Fenton System}

Based on the results obtained in the different experimental runs, a bidimensional quadratic response-surface model was obtained. Good agreement between experimental and calculated data was supported by $R^{2}$ values $\left(R^{2} L S W=0.92, R^{2} S W=0.97\right)$. Model equations can be found in Supplementary Material, Equation (S1). In order to visualize the effect of the studied operational variables, bi-dimensional contour plots, together with the interaction effect plot are represented in Figure 4. 3D contour plots are represented in Figure S1. 
Table 2. Experimental points used in the Doehlert matrix and associated response, which is based on the time required to degrade the sum of CECs to $50 \%$ of its initial concentration $\left(t_{50 \%}\right)$.

\begin{tabular}{|c|c|c|c|c|c|c|c|}
\hline \multirow{3}{*}{ Number of Experiments } & \multicolumn{2}{|c|}{ Coded Values } & \multicolumn{2}{|c|}{ Operational Variables } & \multicolumn{3}{|c|}{$t_{50 \%}(\Sigma$ CECs), (min) } \\
\hline & \multirow{2}{*}{$\begin{array}{c}X_{1} \\
\text { (5 Levels) }\end{array}$} & \multirow{2}{*}{$\begin{array}{c}X_{2} \\
\text { (3 Levels) }\end{array}$} & \multirow{2}{*}{$\begin{array}{c}{[\mathrm{CAT}]} \\
\left(\mathrm{mg} \cdot \mathrm{L}^{-1}\right)\end{array}$} & \multirow{2}{*}{$\mathrm{pH}$} & \multicolumn{2}{|c|}{$\mathrm{Fe}(\mathrm{III}) / \mathrm{H}_{2} \mathrm{O}_{2}$} & \multirow{2}{*}{$\frac{\mathrm{Fe}(\mathrm{III}) / \mathrm{S}_{2} \mathrm{O}_{8}{ }^{2-}}{\mathrm{LSW}}$} \\
\hline & & & & & LSW & SW & \\
\hline 1 & 0 & 0 & 13 & 5 & 0.67 & 0.82 & 18.99 \\
\hline 2 & 1.0 & 0 & 25 & 5 & 2.48 & 0.85 & 83.31 \\
\hline 3 & 0.5 & 0.817 & 19 & 7 & 40.31 & 40.49 & 90.16 \\
\hline 4 & -1.0 & 0.000 & 1 & 5 & 9.66 & 22.22 & 34.95 \\
\hline 5 & -0.5 & -0.817 & 7 & 3 & 0.41 & 8.01 & 18.90 \\
\hline 6 & 0.5 & -0.817 & 19 & 3 & 0.39 & 4.16 & 88.96 \\
\hline 7 & -0.5 & 0.817 & 7 & 7 & 82.39 & 76.61 & 43.69 \\
\hline 8 & 0.0 & 0.000 & 13 & 5 & 0.80 & 0.87 & 19.86 \\
\hline 9 & 0.0 & 0.000 & 13 & 5 & 0.76 & 0.82 & 19.08 \\
\hline
\end{tabular}
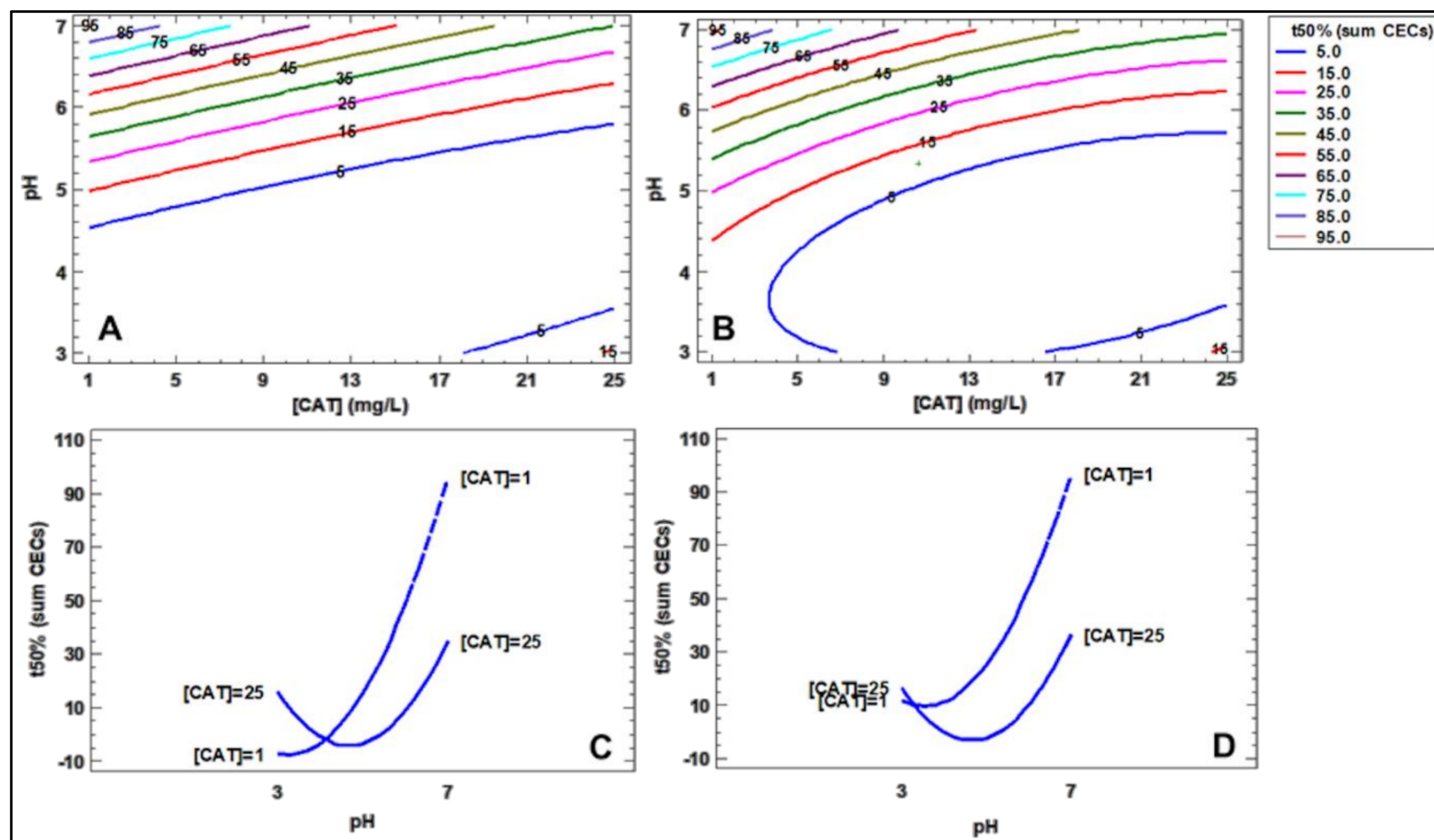

Figure 4. Surface response obtained for the $\Sigma$ CECs in LSW (Left: A,C) and SW (Right: B,D) in a photo-Fenton system with the presence of catechol (CAT) as an assistant (Fe(III) $\left./ \mathrm{H}_{2} \mathrm{O}_{2} / \mathrm{CAT}\right)$. Contour plots of $\mathrm{t}_{50 \%}(\mathbf{A}, \mathbf{B})$ and the interaction effect plot $(\mathbf{C}, \mathbf{D})$ are plotted by means of CAT concentration and $\mathrm{pH}$. Experimental conditions: $[\mathrm{Fe}(\mathrm{III})]=5 \mathrm{mg} \cdot \mathrm{L}^{-1}$, $\left[\mathrm{H}_{2} \mathrm{O}_{2}\right]=146.16 \mathrm{mg} \cdot \mathrm{L}^{-1}$.

For LSW, there is a trend mainly controlled by the $\mathrm{pH}$, in which the $\mathrm{t}_{50 \%}$ increases as the $\mathrm{pH}$ does, in particular at $\mathrm{pH}>5$. However, some interaction among $\mathrm{pH}$ and [CAT] can be found. For instance, a $t_{50 \%}$ of 35 min can be obtained at [CAT] of $1 \mathrm{mg} \mathrm{L}^{-1}$ and $\mathrm{pH} \approx 5.5$; the same $t_{50 \%}$ of $35 \mathrm{~min}$ is reached at $\mathrm{pH} 7$ when the [CAT] $=25 \mathrm{mg} \cdot \mathrm{L}^{-1}$ (Figure $4 \mathrm{~A}$ ). So, it suggests an enhancement of the photo-Fenton process by the addition of catechol. Interestingly, at low $\mathrm{pH}$, a slight detrimental effect of [CAT] is denoted. This can be more easily seen in the interaction effect plot (Figure 4C), where contrary effect is observed at $\mathrm{pH}=3$ and at $\mathrm{pH}=7$. In other words, the presence of catechol clearly assists the photoFenton reaction in the range of near-neutral $\mathrm{pH}$, however it might be a hindrance at low $\mathrm{pH}$, where the photo-Fenton system is known to be highly efficient by itself, hence CAT can compete with the CECs for the reactive species. Thus, it is in agreement with the associated ANOVA table (Table S1) and Pareto charts obtained within the analysis, which 
gives significance $(p<0.05)$ for $\mathrm{pH}$ and its quadratic variable, not for [CAT]. It suggests that the effect of $\mathrm{pH}$ is so pronounced and could mask the effects of the [CAT] for some $\mathrm{pH}$ conditions.

On the other hand, for the SW matrix, significance $(p<0.05)$ was obtained for $\mathrm{pH}$, $\mathrm{pH}^{2},[\mathrm{CAT}]$ and the interaction of them both (Equation (S2)), which means that these two operational factors significantly influence the $t_{50 \%}$ values at $95 \%$ of the confidence level. The effect of salinity (in terms of $\mathrm{Cl}^{-}$concentration) generally seems to decrease the efficiency of the photo-Fenton process at low $\mathrm{pH}$. In fact, the fixed $5 \mathrm{~min}$. line for the $\mathrm{t}_{50 \%}$ is stretched in comparison with LSW (Figure 4B). However, similar trends were observed as with LSW (Figure 2). In addition, the similar trends observed in both water matrices at $\mathrm{pH}>5$ can be explained according to Equations (5)-(8), where the scavenging effect of - $\mathrm{OH}$ radicals by chlorides can be overwhelmed at neutral-basic conditions, since $\mathrm{HOCl}^{\bullet-}$ can revert back to $\mathrm{Cl}^{-}$and ${ }^{\bullet} \mathrm{OH}[44,45]$. Thus, the presence of catechol in SW matrix could help to avoid the negative effect provoked mainly by $\mathrm{pH}$ rather than salinity.

The [CAT] and $\mathrm{H}_{2} \mathrm{O}_{2}$ concentrations were also monitored during the experiments. Catechol achieved $>90 \%$ degradation within the first minutes of reaction in all cases. It implies a fast degradation of this compound within the process, which is in agreement with other studies [26,28], and evidence of the fast photo-oxidation of this ligand [24]. However, this is not a drawback, as the efficiency of the process is kept until the complete removal of the CECs, as observed in Figure 1A. This might imply that byproducts formed from CAT are also good auxiliaries to drive the photo-Fenton reaction at mild $\mathrm{pH}$.

Regarding $\mathrm{H}_{2} \mathrm{O}_{2}$ consumption (Figure S2), some differences between LSW and SW can be found at $\mathrm{pH} 3$ and 7 , but similar consumption rates were obtained in both matrices at $\mathrm{pH}$ 5. These differences can be associated to the efficiency of $\mathrm{H}_{2} \mathrm{O}_{2}$ utilization by the photo-Fenton system and supports the $t_{50 \%}$ values obtained for the $\Sigma$ CECs degradation. It has been reported that CAT-Fe(III) complexes become more stable as the $\mathrm{pH}$ increases, so it implies a slow $\mathrm{H}_{2} \mathrm{O}_{2}$ consumption due to the slow photo-reduction of $\mathrm{Fe}(\mathrm{III})$ and slow $\mathrm{pH}$ decrease during oxidation [26,32,58]. On the other hand, in SW matrices, a worst performance can be also ascertained, especially at $\mathrm{pH}=3$ that could be due to competitive degradation of catechol with CECs. In addition, it might imply low mineralization yields in SW despite the faster removal of the different CECs [59]. Further studies are recommended in this regard.

\subsubsection{Photo-Induced Iron Activation of Persulfate}

In order to gain further insight into the effect of the $\mathrm{pH}$ and [CAT] as operational variables, a quadratic response-surface model was obtained for LSW. Thus, the influence of $\mathrm{pH}$ and [CAT] variables was investigated using $\mathrm{t}_{50 \%}$ as variable response. A bi-dimensional contour plot, together with the interaction effect plot, are represented in Figure 5. The obtained $\mathrm{R}^{2}$ LSW was 0.91 , the model equation was defined on Supplementary Material, Equation (S3). 3D contour plots are represented in Figure S3.

Plots were different when compared with $\mathrm{H}_{2} \mathrm{O}_{2}$, as only the [CAT] variable gains significance $(p<0.05)$. A minimum for $\mathrm{t}_{50 \%}$ was observed at $\mathrm{pH}$ between 4 and 5; [CAT] $=5-10 \mathrm{mg} \mathrm{L}^{-1}$ which means that those were the optimal conditions within the studied region. This indicates that the mechanism of PDS is clearly different to the Fentonlike process, which also support the results obtained in previous sections. Furthermore, $\mathrm{t}_{50 \%}$ values are systematically higher for $\mathrm{Fe} / \mathrm{PDS}$ than for $\mathrm{Fe} / \mathrm{H}_{2} \mathrm{O}_{2}$, indicating the lower efficiency of PDS. However, too high concentrations of CAT are detrimental (Figure 5), as this organic can compete with the pollutants for the reactive species. Even so, an improvement has been obtained in LSW with the presence of CAT $\left(\mathrm{pH}=5\right.$; $\left.[\mathrm{CAT}]_{0}=13 \mathrm{mg} \cdot \mathrm{L}^{-1}\right)$, able to short $\mathrm{t}_{50 \%}$ values at $68 \%$.

Finally, regarding the degradation of CAT itself, it was very fast in most cases, reaching degradation $>90 \%$ within the first minutes of reaction, with some exceptions when $[\mathrm{CAT}]_{0}=19 \mathrm{mg} \cdot \mathrm{L}^{-1}$ (degradation rates of $80 \%$ and $95 \%$ in $15 \mathrm{~min}$ at $\mathrm{pH} 7$ and $\mathrm{pH} 3$, respectively). PDS was also monitored during the reactions, and a higher consumption in the 
presence of CAT was observed (Figure S4A-C); this might indicate that CAT activates iron to catalyze PDS decomposition. On the contrary, experiments conducted in SW resulted in a lower consumption of PDS when compared with LSW, resulting in similar PDS consumption rates with the presence or absence of CAT (Figure S4D, SW). This suggests that high salinity supposes a major hinderance for the Fe/PDS process, even in the presence of CAT, in sharp contrast with the $\mathrm{Fe} / \mathrm{H}_{2} \mathrm{O}_{2}$ system.

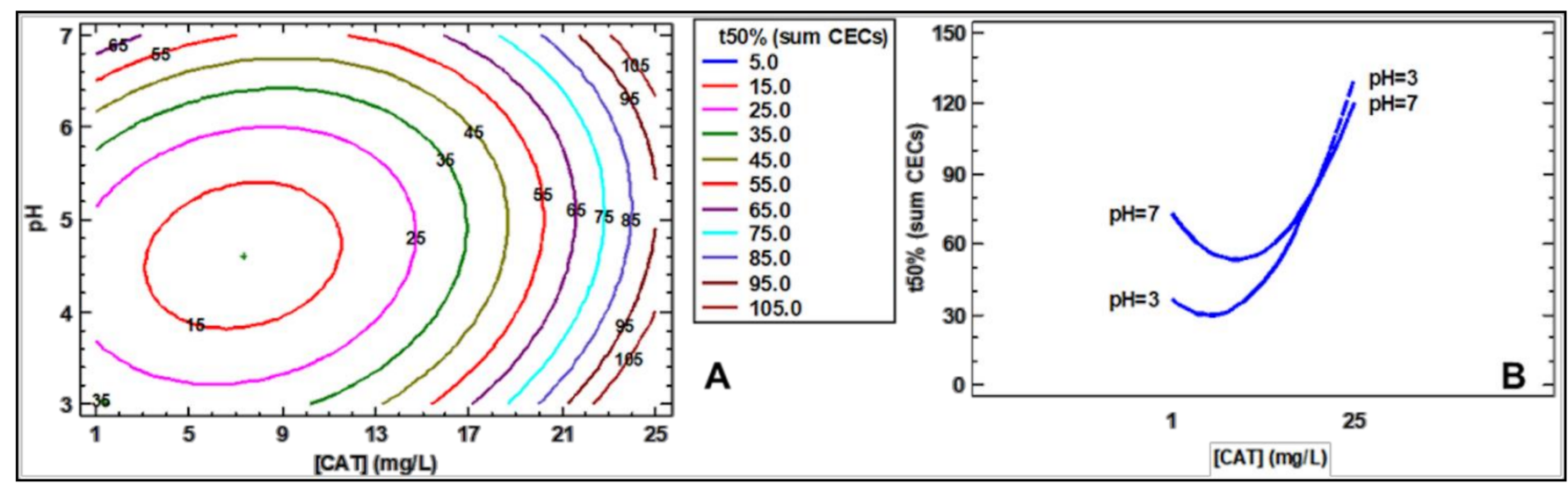

Figure 5. Surface response obtained for the $\Sigma$ CECs in LSW in an irradiated Fe/PDS system with the presence of catechol (CAT) as assistant. Contour plots of $t_{50 \%}$ are plotted by means of CAT concentration and $\mathrm{pH}(\mathrm{A})$ as the interaction effect plot (B). Experimental conditions: $[\mathrm{Fe}(\mathrm{III})]=5 \mathrm{mg} \cdot \mathrm{L}^{-1},\left[\mathrm{~S}_{2} \mathrm{O}_{8}{ }^{2-}\right]=146.16 \mathrm{mg} \cdot \mathrm{L}^{-1}$.

\section{Materials and Methods}

\subsection{Reagents}

High purity (>98\%) Acetamiprid, Acetaminophen, Caffeine, Amoxicillin, Clofibric Acid and Carbamazepine were supplied by Sigma-Aldrich (Madrid, Spain). Catechol, was used as high purity grade reagent $(\geq 95.0 \%$, Sigma-Aldrich).

Fenton-based reactions were performed with iron (III) chloride $\left(\mathrm{FeCl}_{3} \cdot 6 \mathrm{H}_{2} \mathrm{O}\right)$, and hydrogen peroxide $(30 \% w / w)$ purchased from PanReac (Barcelona, Spain). Persulfatebased process were performed with potassium peroxodisulphate, $\mathrm{PDS}\left(\mathrm{K}_{2} \mathrm{~S}_{2} \mathrm{O}_{8}\right), 99.0 \%$ PanReac. When necessary, $\mathrm{pH}$ adjustments were performed with sodium hydroxide and sulfuric acid (PanReac). Water employed in all solutions was of Milli-Q grade. Salinity was modified by adding $\mathrm{NaCl}, 99 \%$ (Panreac) to Milli-Q water. Scavenging tests, were performed with analytical grade 2-propanol and tert-butanol (Sigma-Aldrich). Methanol, formic acid and acetonitrile were HPLC grade and purchased from PanReac.

\subsection{Target Solution and Water Matrices}

The target solution consisted in a mixture of six different CECs, namely acetamiprid, amoxicillin, acetaminophen, caffeine, clofibric acid and carbamazepine. The initial concentration of each was fixed at $5 \mathrm{mg} \cdot \mathrm{L}^{-1}$, which is slightly above the concentration commonly found in ecosystems, but it was chosen to ensure good kinetic data to compare the different processes and reactions.

Two different water matrices were used as aqueous solutions: low salt-water, LSW and salt-water, SW, which was prepared by adding $1 \mathrm{~g} \cdot \mathrm{L}^{-1}$ or $30 \mathrm{~g} \cdot \mathrm{L}^{-1}$ of $\mathrm{NaCl}$ respectively, to distilled water (Milli-Q grade) so as to represent fresh and saline water effluents. Additional tests were also performed in distilled water as control experiments. Initial $\mathrm{pH}$ of the solutions was 5.35 (S.D. \pm 0.12 ) and 4.93 (S.D. \pm 0.34 ), conductivity was determined as 1.68 (S.D. \pm 0.07 ) and 30.7 (S.D. \pm 0.96$) \mathrm{mS} \cdot \mathrm{cm}^{-1}$ for LSW and SW, respectively. The temperature was kept at ca. $30{ }^{\circ} \mathrm{C}$ during the whole experimentation. 


\subsection{Experimental Set-up}

All the experiments were performed in 250-mL cylindrical open glass reactors. A solar simulator (Oriel Instruments, Model 81160 equipped with a 300-W xenon lamp, Oriel Corp. Stratford, CT, USA) was employed as the irradiation source. Specific glass filters for cutting off the transmission of wavelengths $\lambda<300 \mathrm{~nm}$ was used. The UVA irradiance $(315-400 \mathrm{~nm})$ was $32 \mathrm{~W} \cdot \mathrm{m}^{-2}$ [60]. Control experiments showed that direct photolysis of the pollutants was negligible under the employed conditions.

All systems were tested with $5 \mathrm{mg} \cdot \mathrm{L}^{-1}$ of iron, according to previous studies [19,32]. Hydrogen peroxide was added at $146.16 \mathrm{mg} \cdot \mathrm{L}^{-1}$, which is the stoichiometric amount to mineralize the mixture of CECs. It is considered as a useful procedure commonly employed (i) to normalize the amount of $\mathrm{H}_{2} \mathrm{O}_{2}$ added to the reaction medium, and (ii) to ensure that the process is not stopped because of the exhaustion of $\mathrm{H}_{2} \mathrm{O}_{2}$ [19]. The same mass amount of $\mathrm{S}_{2} \mathrm{O}_{8}{ }^{2-}$ was selected for comparative purposes. Main operational factors, such as $\mathrm{pH}$ and the initial concentration of catechol ([CAT $\left.]_{0}\right)$ were varied to assess photo-driven processes.

The same experimental procedure was followed for all tested systems: CECs were prepared in the different aqueous matrices (LSW and SW). Then, reagents were added when required by the experimentation in the following order: (i) catechol, (ii) iron, (iii) $\mathrm{H}_{2} \mathrm{O}_{2}$ or $\mathrm{S}_{2} \mathrm{O}_{8}{ }^{2-}$. It is important to note that when required, the $\mathrm{pH}$ was adjusted to the desired value by dropwise addition of either $0.1 \mathrm{mmol} \mathrm{L}^{-1} \mathrm{NaOH}$ or $0.1 \mathrm{mmol} \mathrm{L}^{-1} \mathrm{H}_{2} \mathrm{SO}_{4}$ before $\mathrm{H}_{2} \mathrm{O}_{2} / \mathrm{S}_{2} \mathrm{O}_{8}{ }^{2-}$ addition. Irradiance was then started, and the experiment was carried out for up to two hours. Samples were periodically taken from the solution to determine the concentration of CECs, catechol, consumption of oxidant, dissolved iron and $\mathrm{pH}$. Those submitted to HPLC analysis were diluted 1:0.4 with methanol to quench the excess of oxidant.

\subsection{Analytical Measurements}

The concentration of each CEC was determined by HPLC (Hitachi Chromaster chromatograph; VWR) with a Chromaster System Manager (v1.1). A Prevail Hichrom column (C18-Select; $250 \times 4.6 \mathrm{~mm} ; 5 \mu \mathrm{m}$ ) was employed as the stationary phase. The mobile phase consisted of a binary mixture of acetonitrile (A) and a $10 \mathrm{mM}$ aqueous solution of formic acid (B). The linear gradient was operated from 10\% A to $90 \%$ A in $25 \mathrm{~min}$. Re-equilibration time was $7 \mathrm{~min}$. A flow rate of $1 \mathrm{~mL} \cdot \mathrm{min}^{-1}$ was used. The wavelength used for the quantification of the CECs was $225 \mathrm{~nm}$. The same procedure was used for monitoring catechol.

$\mathrm{H}_{2} \mathrm{O}_{2}$ measurements were performed through peroxide tests (colorimetric test strips method, 0.5-25 and 1-100 mg/ $\mathrm{L} \mathrm{H}_{2} \mathrm{O}_{2}$ Merckoquant-Merck, Madrid, Spian). In parallel, the PDS and $\mathrm{H}_{2} \mathrm{O}_{2}$ concentrations were measured in all of the experiments spectrophotometrically (UH5300-Hitachi Spectrophotometer) with a iodometric titration and the metavanadate method, respectively $[59,61] . \mathrm{pH}$ and conductivity were determined by the VWR pHenomenal MU61002.

\subsection{Data Treatment}

Time resolved data of the cumulative concentration of the $\Sigma$ CECs were obtained and degradation curves were represented according to the irradiation exposure time. Through these curves, the time required to degrade the CECs mixture to 50\% of its initial concentration $\left(\mathrm{t}_{50 \%}\right)$ can be obtained as variable response through linear interpolation.

A response surface methodology based on Doehlert design was employed as a chemometric tool. This is a convenient methodology to investigate the effect of operational variables [62]. In this study, the efficiency of photo-driven processes was explored in two salinities, i.e., low saltwater $\left(\left[\mathrm{Cl}^{-}\right]=1 \mathrm{~g} \cdot \mathrm{L}^{-1}, \mathrm{LSW}\right)$ and saltwater $\left(\left[\mathrm{Cl}^{-}\right]=30 \mathrm{~g} \cdot \mathrm{L}^{-1}, \mathrm{SW}\right)$, and two oxidants $\left(\mathrm{H}_{2} \mathrm{O}_{2}, \mathrm{~S}_{2} \mathrm{O}_{8}{ }^{2-}\right)$. An experimental domain was defined by considering two different operational factors i.e., $\mathrm{pH}$ which was studied at three levels between 3 and 7 and catechol, concentration of which was varied between 1 and $25 \mathrm{mg} \cdot \mathrm{L}^{-1}$ at 5 levels. 
According to the experimental design, the number of experiments required is given by $\mathrm{N}=\mathrm{k}^{2}+\mathrm{k}+\mathrm{C}_{0}$, where $\mathrm{k}$ is the number of analyzed variables ( 2 in this study) plus two replicates of the central level, $\mathrm{C}_{0}$ Experimental conditions of all experiments can be found in Table 2. The irradiation time required to degrade the sum of the pollutant's concentration to $50 \%$ of its initial value $\left(t_{50 \%}\right)$ was used as the response.

Statistical analysis and response surface model fitting by means of the least squares method was obtained with Statgraphics ${ }^{\circledR}$ Centurion 18 (Version 18.1.12-Statpoints Technologies, Inc., The Plains, VA, USA).

\section{Conclusions}

According to the results obtained, catechol was shown to be a worthy assistant for the photo-Fenton process, in both LSW and SW, since promising times for degrading different CECs were obtained, i.e., $t_{50} \%$ values are reached in less than $60 \mathrm{~min}$ with [CAT] $>7 \mathrm{mg} \cdot \mathrm{L}^{-1}$ in all $\mathrm{pH}$ ranges tested. Best operational ranges are estimated around $\mathrm{pH} 5$ and $[\mathrm{CAT}]=10-15 \mathrm{mg} \cdot \mathrm{L}^{-1}$. The enhancement of the process is clearly stronger in the case of highly saline waters, which is the matrix where the performance is worse. On the other hand, in the PDS system, the [CAT] have a significant influence on the $\Sigma$ CECs degradation, rather than the $\mathrm{pH}$, highlighting that $[\mathrm{CAT}]>15 \mathrm{mg} \cdot \mathrm{L}^{-1}$ implies adverse effects on CECs degradation. The PDS-based system was strongly dependent on salinity conditions and nature of CECs. It is important to highlight that catechol compound is efficiently eliminated in both systems within the degradation process.

The good performance of the CAT-based photo-Fenton reaction in SW is of great interest, as it opens the door to a niche application of these processes, namely the treatment of seawater effluents, such as fish-farms or ballast waters. Moreover, the use of persulfatebased processes might be of interest for the group of pollutants that show scarce selectivity between hydroxyl radical and other less reactive species.

It is noteworthy indicating that phenolic moieties can be found in humic substances, that have been demonstrated to enhance the photo-Fenton reaction at mild $\mathrm{pH}$, although its structure is too complex to perform an accurate mechanistic study. If catechol (and in general phenolic moieties) can be assumed to be among the active sites of these macromolecules, they can be proposed as models to gain further insight into the role of humic substances in the photo-oxidation of xenobiotics. Hence, further research to study the role of other aromatics moieties (e.g., phenolic acids) might be of interest in the future, but also research on the involvement of transient reactive species by means of photophysical measurements.

Supplementary Materials: The following are available online at https:/ / www.mdpi.com/2073-434 4/11/3/372/s1, Equations (S1)-(S3): Response surface models obtained; Figure S1: 3D estimated response surface obtained for the $\Sigma$ CECs in LSW and SW in the photo-Fenton system with the presence of catechol (CAT) as assistant (Fe(III)/H2O2/CAT); Figure S2: H2O2 consumption for the photo-Fenton system at different operational conditions in the different studied water matrices; Figure S3: 3D estimated response surface obtained for the $\Sigma$ CECs in LSW with the presence of catechol (CAT) as assistant (Fe(III)/PDS/CAT); Figure S4: PDS consumption for the irradiated $\mathrm{Fe}(\mathrm{III}) / \mathrm{PDS} / \mathrm{CAT}$ system at different operational conditions in LSW and SW; Table S1-S3: Analysis of variance (ANOVA).

Author Contributions: Conceptualization, J.M.-A. and A.A.; methodology, J.M.-A., L.S.-J. and A.A.; validation, J.M.-A., L.S.-J. and A.A.; formal analysis, J.M.-A., P.G.-N.; investigation, J.M.-A., I.V. and P.G.-N.; resources, A.A.; data curation, J.M.-A., I.V. and P.G.-N.; writing-original draft preparation, J.M.-A. and A.A.; writing-review and editing, J.M.-A., L.S.-J., P.G.-N. and A.A.; visualization, J.M.-A. and A.A.; supervision, A.A.; project administration, A.A.; funding acquisition, J.M.-A. and A.A. All authors have read and agreed to the published version of the manuscript. 
Funding: This research was funded by Spanish Ministry of Science, Innovation and Universities, AEI and FEDER for funding under the CalypSol Project (Ref: RTI2018-097997-B-C31) and the co-funding by the 2014-2020 ERDF Operational Programme and by the Department of Economy, Knowledge, Business and University of the Regional Government of Andalusia (Spain). Ref.: FEDER-UCA18108023. J. Moreno-Andrés is grateful to Generalitat Valenciana (Spain) (APOSTD/2019/207) and the financial support from the European Social Fund (ESF).

Conflicts of Interest: The authors declare no conflict of interest.

\section{References}

1. Rizzo, L.; Malato, S.; Antakyali, D.; Beretsou, V.G.; Đolić, M.B.; Gernjak, W.; Heath, E.; Ivancev-Tumbas, I.; Karaolia, P.; Lado Ribeiro, A.R.; et al. Consolidated vs. new advanced treatment methods for the removal of contaminants of emerging concern from urban wastewater. Sci. Total Environ. 2019, 655, 986-1008. [CrossRef]

2. Fenton, H.J.H. Oxidation of tartaric acid in presence of iron. J. Chem. Soc. Trans. 1894, 65, 899-910. [CrossRef]

3. Haber, F.; Weiss, J. The catalytic decomposition of hydrogen peroxide by iron salts. Proc. R. Soc. Lond. Ser. A Math. Phys. Sci. 1934, 147, 332-351. [CrossRef]

4. Pignatello, J.J.; Oliveros, E.; MacKay, A. Advanced oxidation processes for organic contaminant destruction based on the fenton reaction and related chemistry. Crit. Rev. Environ. Sci. Technol. 2006, 36, 1-84. [CrossRef]

5. Barb, W.G.; Baxendale, J.H.; George, P.; Hargrave, K.R. Reactions of ferrous and ferric ions with hydrogen peroxide. Part II.-The ferric ion reaction. Trans. Faraday Soc. 1951, 47, 591-616. [CrossRef]

6. Gligorovski, S.; Strekowski, R.; Barbati, S.; Vione, D. Environmental Implications of Hydroxyl Radicals (•OH). Chem. Rev. 2015, 115, 13051-13092. [CrossRef]

7. Pérez-Almeida, N.; González, A.G.; Santana-Casiano, J.M.; González-Dávila, M. Iron and copper redox interactions in UVseawater: A kinetic model approach. Chem. Geol. 2019, 506, 149-161. [CrossRef]

8. Lueder, U.; Jørgensen, B.B.; Kappler, A.; Schmidt, C. Photochemistry of iron in aquatic environments. Environ. Sci. Process. Impacts 2020, 22, 12-24. [CrossRef]

9. Giannakis, S.; López, M.I.P.; Spuhler, D.; Pérez, J.A.S.; Ibáñez, P.F.; Pulgarin, C. Solar disinfection is an augmentable, in situgenerated photo-Fenton reaction-Part 2: A review of the applications for drinking water and wastewater disinfection. Appl. Catal. B Environ. 2016, 198, 431-446. [CrossRef]

10. Olmez-Hanci, T.; Arslan-Alaton, I. Comparison of sulfate and hydroxyl radical based advanced oxidation of phenol. Chem. Eng. J. 2013, 224, 10-16. [CrossRef]

11. Clarizia, L.; Russo, D.; Di Somma, I.; Marotta, R.; Andreozzi, R. Homogeneous photo-Fenton processes at near neutral pH: A review. Appl. Catal. B Environ. 2017, 209, 358-371. [CrossRef]

12. Dong, H.; Qiang, Z.; Hu, J.; Sans, C. Accelerated degradation of iopamidol in iron activated persulfate systems: Roles of complexing agents. Chem. Eng. J. 2017, 316, 288-295. [CrossRef]

13. Sandy, M.; Butler, A. Microbial iron acquisition: Marine and terrestrial siderophores. Chem. Rev. 2009, 109, 4580-4595. [CrossRef]

14. Gledhill, M.; Buck, K.N. The organic complexation of iron in the marine environment: A review. Front. Microbiol. 2012, 3, 1-17. [CrossRef] [PubMed]

15. Avdeef, A.; Sofen, S.R.; Bregante, T.L.; Raymond, K.N. Coordination chemistry of microbial iron transport compounds. 9.1 Stability constants for catechol models of enterobactin. J. Am. Chem. Soc. 1978, 100, 5362-5370. [CrossRef]

16. Årstøl, E.; Hohmann-Marriott, M.F. Cyanobacterial siderophores-Physiology, structure, biosynthesis, and applications. Mar. Drugs 2019, 17, 281. [CrossRef]

17. García-Negueroles, P.; García-Ballesteros, S.; Amat, A.M.; Laurenti, E.; Arques, A.; Santos-Juanes, L. Unveiling the dependence between hydroxyl radical generation and performance of fenton systems with complexed iron. ACS Omega 2019, 4, 21698-21703. [CrossRef] [PubMed]

18. García-Ballesteros, S.; Grimalt, J.; Berto, S.; Minella, M.; Laurenti, E.; Vicente, R.; López-Pérez, M.F.; Amat, A.M.; Bianco Prevot, A.; Arques, A. New route for valorization of oil mill wastes: Isolation of humic-like substances to be employed in solar-driven processes for pollutants removal. ACS Omega 2018, 3, 13073-13080. [CrossRef] [PubMed]

19. Gomis, J.; Carlos, L.; Bianco Prevot, A.; Teixeira, A.C.S.C.; Mora, M.; Amat, A.M.; Vicente, R.; Arques, A. Bio-based substances from urban waste as auxiliaries for solar photo-Fenton treatment under mild conditions: Optimization of operational variables. Catal. Today 2015, 240, 39-45. [CrossRef]

20. Whitby, H.; Planquette, H.; Cassar, N.; Bucciarelli, E.; Osburn, C.L.; Janssen, D.J.; Cullen, J.T.; González, A.G.; Völker, C.; Sarthou, G. A call for refining the role of humic-like substances in the oceanic iron cycle. Sci. Rep. 2020, 10, 6144. [CrossRef] [PubMed]

21. Huang, X.; Peng, Y.; Xu, J.; Wu, F.; Mailhot, G. Iron(III)-induced photooxidation of arsenite in the presence of carboxylic acids and phenols as model compounds of natural organic matter. Chemosphere 2021, 263, 128142. [CrossRef]

22. Xu, S.; Zhao, J.; Yu, Q.; Qiu, X.; Sasaki, K. Understanding how specific functional groups in humic acid affect the sorption mechanisms of different calcinated layered double hydroxides. Chem. Eng. J. 2020, 392, 123633. [CrossRef]

23. Perron, N.R.; Wang, H.C.; Deguire, S.N.; Jenkins, M.; Lawson, M.; Brumaghim, J.L. Kinetics of iron oxidation upon polyphenol binding. Dalt. Trans. 2010, 39, 9982-9987. [CrossRef] 
24. Barbeau, K.; Rue, E.L.; Trick, C.G.; Bruland, K.W.; Butler, A. Photochemical reactivity of siderophores produced by marine heterotrophic bacteria and cyanobacteria based on characteristic Fe(III) binding groups. Limnol. Oceanogr. 2003, 48, 1069-1078. [CrossRef]

25. Chen, F.; Ma, W.; He, J.; Zhao, J. Fenton degradation of malachite green catalyzed by aromatic additives. J. Phys. Chem. A 2002, 106, 9485-9490. [CrossRef]

26. Xiao, J.; Wang, C.; Liu, H. Fenton-like degradation of dimethyl phthalate enhanced by quinone species. J. Hazard. Mater. 2020, 382, 121007. [CrossRef]

27. Santana-Casiano, J.M.; González-Dávila, M.; González, A.G.; Millero, F.J. Fe(III) reduction in the presence of Catechol in seawater. Aquat. Geochem. 2010, 16, 467-482. [CrossRef]

28. Zanta, C.L.P.S.; Friedrich, L.C.; Machulek, A.; Higa, K.M.; Quina, F.H. Surfactant degradation by a catechol-driven Fenton reaction. J. Hazard. Mater. 2010, 178, 258-263. [CrossRef] [PubMed]

29. Nichela, D.A.; Donadelli, J.A.; Caram, B.F.; Haddou, M.; Rodriguez Nieto, F.J.; Oliveros, E.; García Einschlag, F.S. Iron cycling during the autocatalytic decomposition of benzoic acid derivatives by Fenton-like and photo-Fenton techniques. Appl. Catal. B Environ. 2015, 170-171, 312-321. [CrossRef]

30. Calza, P.; Campra, L.; Pelizzetti, E.; Minero, C. Role of H2O2 in the photo-transformation of phenol in artificial and natural seawater. Sci. Total Environ. 2012, 431, 84-91. [CrossRef] [PubMed]

31. Lofrano, G.; Rizzo, L.; Grassi, M.; Belgiorno, V. Advanced oxidation of catechol: A comparison among photocatalysis, Fenton and photo-Fenton processes. Desalination 2009, 249, 878-883. [CrossRef]

32. Xiao, J.; Wang, C.; Lyu, S.; Liu, H.; Jiang, C.; Lei, Y. Enhancement of Fenton degradation by catechol in a wide initial pH range. Sep. Purif. Technol. 2016, 169, 202-209. [CrossRef]

33. Lulijwa, R.; Rupia, E.J.; Alfaro, A.C. Antibiotic use in aquaculture, policies and regulation, health and environmental risks: A review of the top 15 major producers. Rev. Aquac. 2019, 2000, 1-24. [CrossRef]

34. Ganiyu, S.O.; Van Hullebusch, E.D.; Cretin, M.; Esposito, G.; Oturan, M.A. Coupling of membrane filtration and advanced oxidation processes for removal of pharmaceutical residues: A critical review. Sep. Purif. Technol. 2015, 156, 891-914. [CrossRef]

35. García-Vaquero, N.; Lee, E.; Jiménez Castañeda, R.; Cho, J.; López-Ramírez, J.A. Comparison of drinking water pollutant removal using a nanofiltration pilot plant powered by renewable energy and a conventional treatment facility. Desalination 2014, 347, 94-102. [CrossRef]

36. Vicente-Cera, I.; Moreno-Andrés, J.; Amaya-Vías, D.; Biel-Maeso, M.; Pintado-Herrera, M.G.; Lara-Martín, P.A.; Acevedo-Merino, A.; López-Ramírez, J.A.; Nebot, E. Chemical and microbiological characterization of cruise vessel wastewater discharges under repair conditions. Ecotoxicol. Environ. Saf. 2019, 169, 68-75. [CrossRef]

37. Carra, I.; Sánchez Pérez, J.A.; Malato, S.; Autin, O.; Jefferson, B.; Jarvis, P. Performance of different advanced oxidation processes for tertiary wastewater treatment to remove the pesticide acetamiprid. J. Chem. Technol. Biotechnol. 2016, 91, 72-81. [CrossRef]

38. Gavrilescu, M.; Demnerová, K.; Aamand, J.; Agathos, S.; Fava, F. Emerging pollutants in the environment: Present and future challenges in biomonitoring, ecological risks and bioremediation. N. Biotechnol. 2015, 32, 147-156. [CrossRef]

39. Álvarez-Muñoz, D.; Llorca, M.; Blasco, J.; Barceló, D. Chapter 1-Contaminants in the Marine Environment; Blasco, J., Chapman, P.M., Campana, O., Hampel, M., Eds.; Academic Press: Cambridge, MA, USA, 2016; pp. 1-34, ISBN 9780128033715. [CrossRef]

40. Lara-Martín, P.A.; Chiaia-Hernández, A.C.; Biel-Maeso, M.; Baena-Nogueras, R.M.; Hollender, J. Tracing urban wastewater contaminants into the atlantic ocean by nontarget screening. Environ. Sci. Technol. 2020, 54, 3996-4005. [CrossRef]

41. Gomis, J.; Bianco Prevot, A.; Montoneri, E.; González, M.C.; Amat, A.M.; Mártire, D.O.; Arques, A.; Carlos, L. Waste sourced bio-based substances for solar-driven wastewater remediation: Photodegradation of emerging pollutants. Chem. Eng. J. 2014, 235, 236-243. [CrossRef]

42. Wu, Y.; Monfort, O.; Dong, W.; Brigante, M.; Mailhot, G. Enhancement of iron-mediated activation of persulfate using catechin: From generation of reactive species to atenolol degradation in water. Sci. Total Environ. 2019, 697. [CrossRef]

43. Kiwi, J.; Lopez, A.; Nadtochenko, V. Mechanism and kinetics of the OH-radical intervention during Fenton oxidation in the presence of a significant amount of radical scavenger (Cl-). Environ. Sci. Technol. 2000, 34, 2162-2168. [CrossRef]

44. Rommozzi, E.; Giannakis, S.; Giovannetti, R.; Vione, D.; Pulgarin, C. Detrimental vs. beneficial influence of ions during solar (SODIS) and photo-Fenton disinfection of E. coli in water: (bi)carbonate, chloride, nitrate and nitrite effects. Appl. Catal. B Environ. 2020, 270, 118877. [CrossRef]

45. Machulek Amilcar, J.; Moraes Jose, E.F.; Vautier-Giongo, C.; Silverio Cristina, A.; Friedrich Leidi, C.; Nascimento Claudio, A.O.; Gonzalez Monica, C.; Quina Frank, H. Abatement of the inhibitory effect of chloride anions on the photo-Fenton process. Environ. Sci. Technol. 2007, 41, 8459-8463. [CrossRef]

46. Yang, Y.; Pignatello, J.J.; Ma, J.; Mitch, W.A. Comparison of halide impacts on the efficiency of contaminant degradation by sulfate and hydroxyl radical-based advanced oxidation processes (AOPs). Environ. Sci. Technol. 2014, 48, 2344-2351. [CrossRef]

47. Moreno-Andrés, J.; Farinango, G.; Romero-Martínez, L.; Acevedo-Merino, A.; Nebot, E. Application of persulfate salts for enhancing UV disinfection in marine waters. Water Res. 2019, 163, 114866. [CrossRef] [PubMed]

48. Nihemaiti, M.; Miklos, D.B.; Hübner, U.; Linden, K.G.; Drewes, J.E.; Croué, J.P. Removal of trace organic chemicals in wastewater effluent by UV/H2O2and UV/PDS. Water Res. 2018, 145, 487-497. [CrossRef] [PubMed]

49. Lei, Y.; Cheng, S.; Luo, N.; Yang, X.; An, T. Rate constants and mechanisms of the reactions of Cl• and Cl2•- with Trace Organic Contaminants. Environ. Sci. Technol. 2019, 53, 11170-11182. [CrossRef] 
50. Ye, T.; Wei, Z.; Spinney, R.; Tang, C.J.; Luo, S.; Xiao, R.; Dionysiou, D.D. Chemical structure-based predictive model for the oxidation of trace organic contaminants by sulfate radical. Water Res. 2017, 116, 106-115. [CrossRef] [PubMed]

51. Lu, X.; Shao, Y.; Gao, N.; Chen, J.; Deng, H.; Chu, W.; An, N.; Peng, F. Investigation of clofibric acid removal by UV/persulfate and UV/chlorine processes: Kinetics and formation of disinfection byproducts during subsequent chlor(am)ination. Chem. Eng. J. 2018, 331, 364-371. [CrossRef]

52. Li, B.; Ma, X.; Deng, J.; Li, Q.; Chen, W.; Li, G.; Chen, G.; Wang, J. Comparison of acetaminophen degradation in UV-LED-based advance oxidation processes: Reaction kinetics, radicals contribution, degradation pathways and acute toxicity assessment. Sci. Total Environ. 2020, 723, 137993. [CrossRef]

53. Deemter, D.; Oller, I.; Amat, A.M.; Malato, S. Effect of salinity on preconcentration of contaminants of emerging concern by nanofiltration: Application of solar photo-Fenton as a tertiary treatment. Sci. Total Environ. 2020, 756, 143593. [CrossRef] [PubMed]

54. Neta, P.; Madhavan, V.; Zemel, H.; Fessenden, R.W. Rate Constants and Mechanism of Reaction of sulfate radical anion with Aromatic Compounds. J. Am. Chem. Soc. 1977, 99, 163-164. [CrossRef]

55. Buxton, G.V.; Greenstock, C.L.; Helman, W.P.; Ross, A.B. Critical Review of rate constants for reactions of hydrated electrons, hydrogen atoms and hydroxyl radicals (OH/O-) in Aqueous Solution. J. Phys. Chem. Ref. Data 1988, 17, 513-886. [CrossRef]

56. Neta, P.; Huie, R.E.; Ross, A.B. Rate Constants for Reactions of Inorganic Radicals in Aqueous Solution. J. Phys. Chem. Ref. Data 1988, 17, 1027-1284. [CrossRef]

57. Wang, L.; Zhang, Q.; Chen, B.; Bu, Y.; Chen, Y.; Ma, J.; Rosario-Ortiz, F.L.; Zhu, R. Some issues limiting photo(cata)lysis application in water pollutant control: A critical review from chemistry perspectives. Water Res. 2020, 174, 115605. [CrossRef] [PubMed]

58. Nichela, D.; Haddou, M.; Benoit-Marquié, F.; Maurette, M.T.; Oliveros, E.; García Einschlag, F.S. Degradation kinetics of hydroxy and hydroxynitro derivatives of benzoic acid by fenton-like and photo-fenton techniques: A comparative study. Appl. Catal. $B$ Environ. 2010, 98, 171-179. [CrossRef]

59. Sciscenko, I.; Garcia-Ballesteros, S.; Sabater, C.; Castillo, M.A.; Escudero-Oñate, C.; Oller, I.; Arques, A. Monitoring photolysis and (solar photo)-Fenton of enrofloxacin by a methodology involving EEM-PARAFAC and bioassays: Role of $\mathrm{pH}$ and water matrix. Sci. Total Environ. 2020, 719, 137331. [CrossRef]

60. Santos-Juanes, L.; García Einschlag, F.S.; Amat, A.M.; Arques, A. Combining ZVI reduction with photo-Fenton process for the removal of persistent pollutants. Chem. Eng. J. 2017, 310, 484-490. [CrossRef]

61. Liang, C.; Huang, C.F.; Mohanty, N.; Kurakalva, R.M. A rapid spectrophotometric determination of persulfate anion in ISCO. Chemosphere 2008, 73, 1540-1543. [CrossRef] [PubMed]

62. Ferreira, S.L.C.; Dos Santos, W.N.L.; Quintella, C.M.; Neto, B.B.; Bosque-Sendra, J.M. Doehlert matrix: A chemometric tool for analytical chemistry—Review. Talanta 2004, 63, 1061-1067. [CrossRef] [PubMed] 